\title{
Lower back pain in a patient on long-term haemodialysis
}

\author{
Roberta Callus, ${ }^{1}$ Richard Pullicino, ${ }^{2}$ Louis Buhagiar, ${ }^{1}$ Adrian Mizzi ${ }^{2}$
}

${ }^{1}$ Department of Medicine, Mater Dei Hospital, Msida, Malta

${ }^{2}$ Department of Medical Imaging, Mater Dei Hospital Msida, Malta

\section{Correspondence to}

Dr Roberta Callus, robertacallus@yahoo.co.uk

Accepted 31 May 2014

\section{DESCRIPTION}

A 60-year-old woman with end-stage renal disease secondary to adult polycystic kidney disease, presented with a 6-month history of worsening sacral and rectal pain. She reported anorexia and significant weight loss. She was on haemodialysis for 5 years prior to receiving a renal transplant, which failed after 8 years. She was then recommenced haemodialysis for another 4 years to date. She underwent bilateral nephrectomy of her native kidneys prior to transplantation. Clinical examination showed cachexia, hepatomegaly and a right iliac fossa graft. Rectal examination was normal. Passive movements of both lower limbs were painful; however, there was no neurological deficit.

Investigations showed a chronic normocytic anaemia despite high doses of erythropoeitin and adequate iron stores. Secondary hyperparathyroidism progressed despite treatment with alfacalcidol and phosphate binders. Serum calcium was
$2.40 \mathrm{mmol} / \mathrm{L}$ (normal $2.05-2.55 \mathrm{mmol} / \mathrm{L}$ ); phosphate $1.63 \mathrm{mmol} / \mathrm{L}$ (normal $0.87-1.45 \mathrm{mmol} / \mathrm{L}$ ); alkaline phosphatase $503 \mathrm{U} / \mathrm{L}$ (normal 40-104 U/L) and parathyroid hormone $2053 \mathrm{pg} / \mathrm{mL}$ (target 150 $300 \mathrm{pg} / \mathrm{mL})$. CT imaging revealed a sacral mass (figures 1-3).

Brown tumours are more common in primary compared with secondary hyperparathyroidism. ${ }^{1}$ In this case the severe hyperparathyroidism was attributed to a long history of advanced chronic kidney disease, as well as poor phosphate control. Thirty-seven cases of brown tumours affecting the spine have been reported in the literature, all presenting with symptoms and signs of cord compression. ${ }^{2}$ The thoracic spine was affected in $58.3 \%$ of cases. $^{2}$ Treatment options include decompression surgery and/or parathyroidectomy. Osteoclastomas may be prevented by prompt diagnosis and treatment of hyperparathyroidism in chronic kidney disease as well as in renal transplant patients.

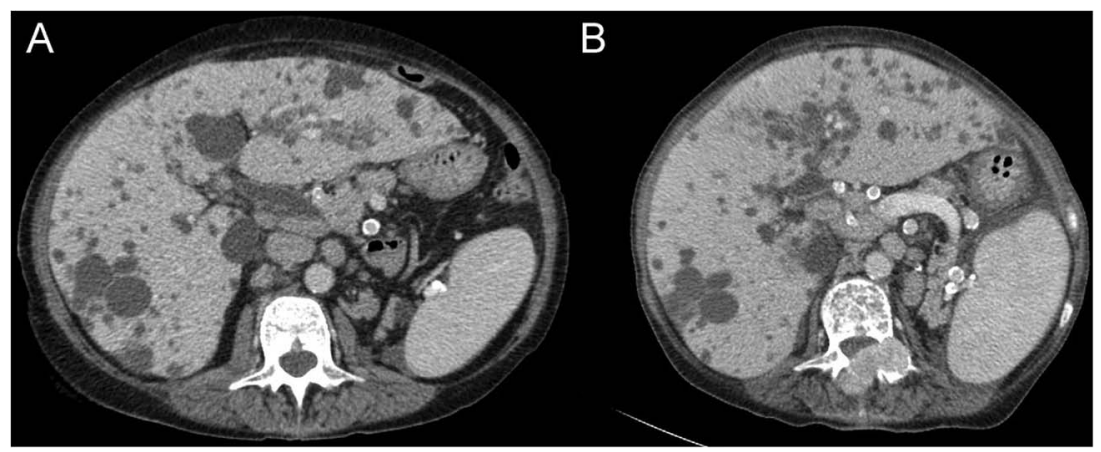

Figure 1 (A) Axial CT image at the level of L2 vertebral body shows multiple simple cysts scattered in both liver lobes. (B) Follow-up CTs taken 3 years apart demonstrate interval development of a lobulated soft tissue mass centred in the left posterior elements of L1. The lesion extends medially and causes narrowing of the central canal.

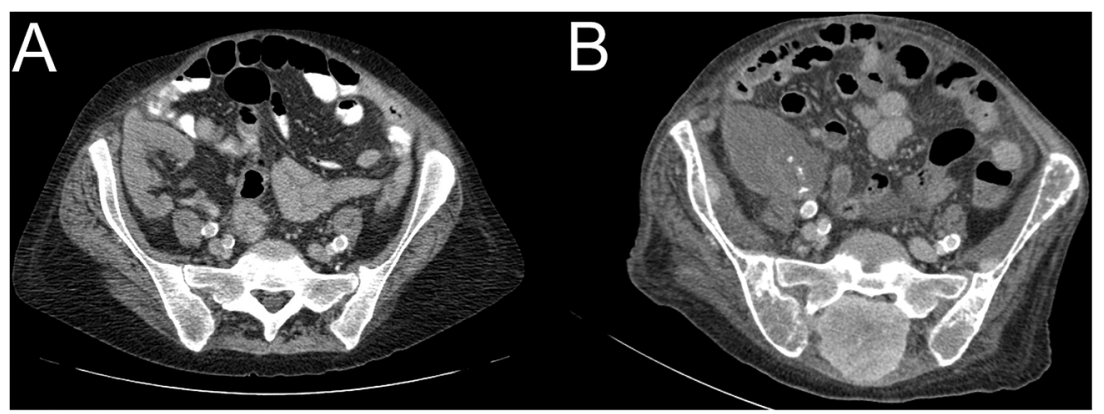

Figure 2 Axial CT images through the pelvis taken 3 years apart. (A) A renal transplant is noted in the right iliac fossa and appears within normal limits. The visualised sacrum and ilia are unremarkable. (B) There is loss of cortico-medullary differentiation in keeping with a failed renal graft. A soft tissue mass is seen in the dorsal aspect of the sacrum which extends into the sacral canal. Note decreased mineralisation in the iliac wings in keeping with osteomalacia.

To cite: Callus $R$, Pullicino R, Buhagiar L, et al. BMJ Case Rep Published online: [please include Day Month Year doi:10.1136/bcr-2014 205110 


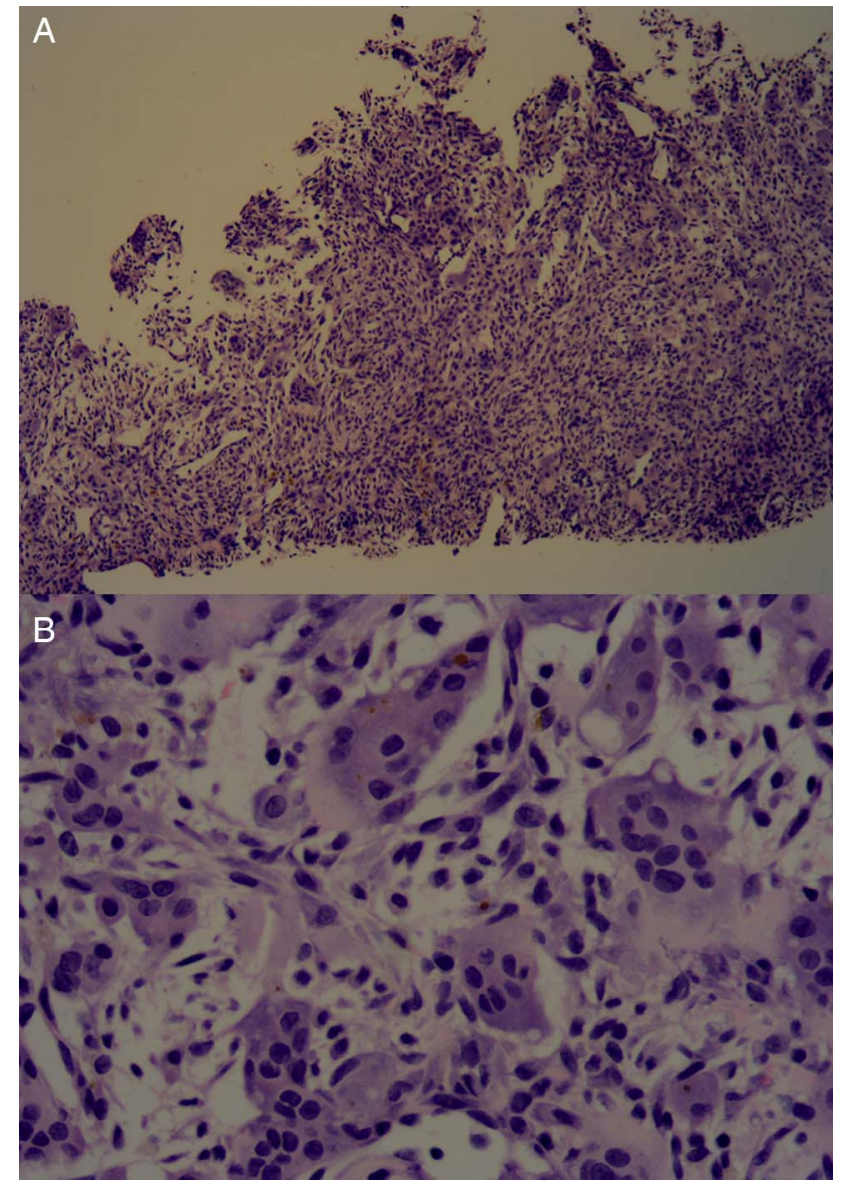

Figure 3 A biopsy of the mass showed vascularised fibrous tissue with osteoclast-type giant cells. These cells have a haphazard arrangement favouring the diagnosis of a spinal osteoclastoma (brown tumour). Also note the brown haemosiderin deposition (A-H\&E stain $\times 100$; B-H\&E stain $\times 400$ ).

\section{Learning points}

- Brown tumours should be considered in the differential diagnosis of a spinal mass in a patient with long-standing chronic kidney disease.

- Regular monitoring and prompt treatment of mineral bone disorders in chronic kidney disease, according to established guidelines, is important.

- Spinal cord compression is a frequent complication of spinal brown tumours.

Acknowledgements We would like to thank Dr Noel Gatt, consultant histopathologist for providing the histology images for this case.

Competing interests None.

Patient consent Obtained.

Provenance and peer review Not commissioned; externally peer reviewed.

\section{REFERENCES}

1 Mak KC, Wong YW, Luk KD. Spinal cord compression secondary to brown tumour in a patient on long-term haemodialysis: a case report. J Orthop Surg 2009;17:90-5.

2 Arsalanizadeh B, Westacott R. Osteoclastomas ('brown tumours') and spinal cord compression: a review. Clin Kidney J 2013;6:220-3.

Copyright 2014 BMJ Publishing Group. All rights reserved. For permission to reuse any of this content visit

http://group.bmj.com/group/rights-licensing/permissions.

BMJ Case Report Fellows may re-use this article for personal use and teaching without any further permission.

Become a Fellow of BMJ Case Reports today and you can:

- Submit as many cases as you like

- Enjoy fast sympathetic peer review and rapid publication of accepted articles

- Access all the published articles

- Re-use any of the published material for personal use and teaching without further permission

For information on Institutional Fellowships contact consortiasales@bmjgroup.com

Visit casereports.bmj.com for more articles like this and to become a Fellow 